Section Editor

John J. Millichap, MD

Rachid Madkouri, MD

Michael Grelat, MD

Correspondence to

Dr. Grelat:

michael.grelat@gmail.com

\section{Teaching NeuroImages: \\ Superficial siderosis due to a dural cervical arteriovenous fistula}
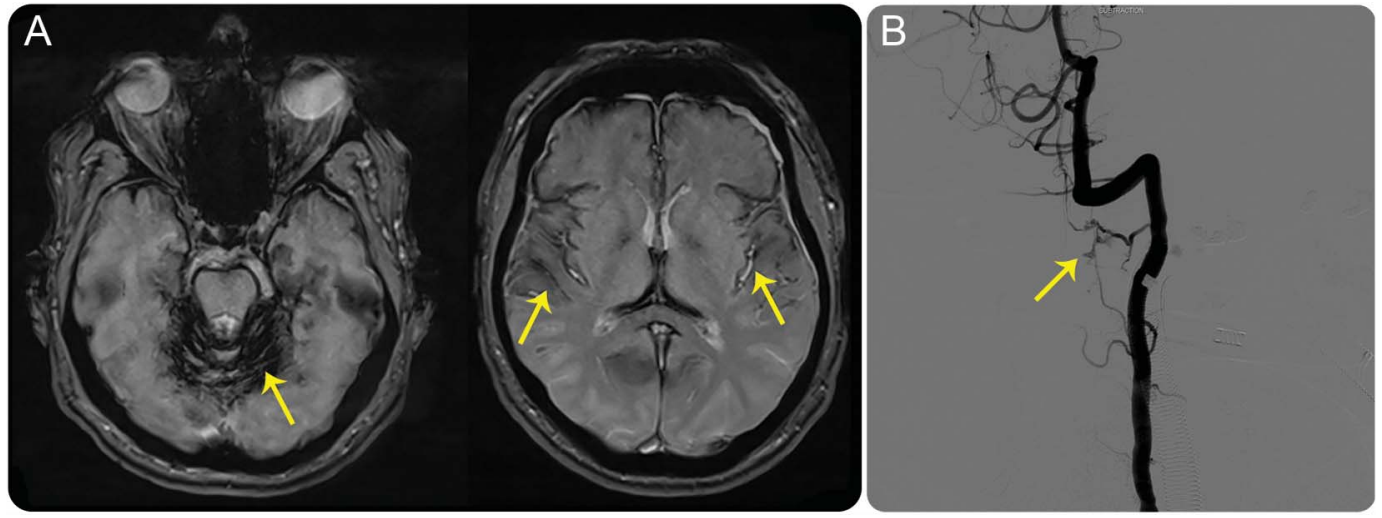

(A) Axial T2-weighted gradient echo MRI shows hemosiderin deposition in supratentorial brain (inside of sulcus) and in infratentorial brain (on the surface of the brainstem and the cerebellum). (B) Cerebral angiography: dural arteriovenous fistula in the C1-C2 left foramen, fed by meningeal branches of the vertebral artery.

A 58-year-old man presented to our hospital with cerebellar ataxia, pyramidal signs, dysarthria, bilateral deafness, and cognitive impairment. These symptoms were consistent with superficial siderosis (SS) of the CNS, confirmed by MRI (figure A). ${ }^{1}$ Cerebral angiography showed a dural arteriovenous fistula perispinal and pontic with venous drainage in the left foramen $\mathrm{C} 1-\mathrm{C} 2$, fed by meningeal branches of the vertebral artery (figure, B). The fistulous point was clipped. SS of CNS is a rare disease resulting from hemosiderin deposition on the surface of the CNS and cranial nerves. ${ }^{2}$ At diagnosis, the etiology may not be known. Finding etiology is necessary (trauma, vascular malformation). ${ }^{2}$

\section{AUTHOR CONTRIBUTIONS}

Rachid Madkouri evaluated the patient and wrote the manuscript. Michael Grelat prepared the images and legends and finalized the manuscript.

\section{STUDY FUNDING}

No targeted funding reported.

\section{DISCLOSURE}

The authors report no disclosures relevant to the manuscript. Go to Neurology.org for full disclosures.

\section{REFERENCES}

1. Koeppen AH, Michael SC, Li D, et al. The pathology of superficial siderosis of the central nervous system. Acta Neuropathol 2008;116:371-382.

2. Kumar N, Cohen-Gadol AA, Wright RA, Miller GM, Piepgras DG, Ahlskog JE. Superficial siderosis. Neurology 2006;66:1144-1152.
Download teaching slides: Neurology.org 


\section{Neurology}

\section{Teaching NeuroImages: Superficial siderosis due to a dural cervical arteriovenous fistula}

Rachid Madkouri and Michael Grelat

Neurology 2017;88;e66

DOI 10.1212/WNL.0000000000003638

This information is current as of February 20, 2017

\section{Updated Information \&} Services

Supplementary Material

\section{References}

Subspecialty Collections

Permissions \& Licensing

Reprints including high resolution figures, can be found at: http://n.neurology.org/content/88/8/e66.full

Supplementary material can be found at: http://n.neurology.org/content/suppl/2017/02/21/WNL.0000000000003 638.DC1

This article cites 2 articles, 1 of which you can access for free at: http://n.neurology.org/content/88/8/e66.full\#ref-list-1

This article, along with others on similar topics, appears in the following collection(s):

All Cerebrovascular disease/Stroke

http://n.neurology.org/cgi/collection/all_cerebrovascular_disease_strok e

All Spinal Cord

http://n.neurology.org/cgi/collection/all_spinal_cord Arteriovenous malformation

http://n.neurology.org/cgi/collection/arteriovenous_malformation Subarachnoid hemorrhage

http://n.neurology.org/cgi/collection/subarachnoid_hemorrhage

Information about reproducing this article in parts (figures,tables) or in its entirety can be found online at:

http://www.neurology.org/about/about_the_journal\#permissions

Information about ordering reprints can be found online:

http://n.neurology.org/subscribers/advertise

Neurology ${ }^{\circledR}$ is the official journal of the American Academy of Neurology. Published continuously since 1951, it is now a weekly with 48 issues per year. Copyright @ 2017 American Academy of Neurology. All rights reserved. Print ISSN: 0028-3878. Online ISSN: 1526-632X.

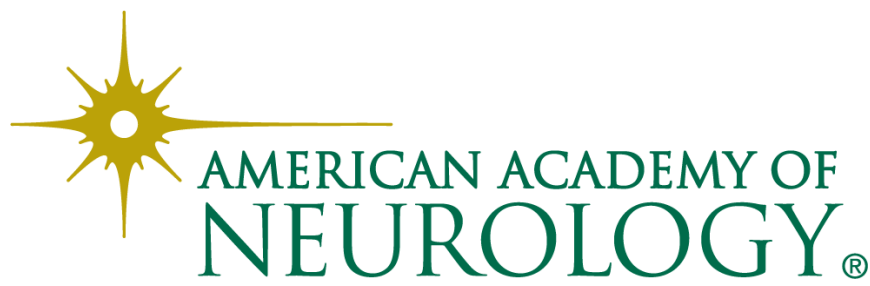

